ARTICLE

https://doi.org/10.1057/s41599-020-0461-0 \\ OPEN
}

\section{Immigration/migration and healthy publics: the threat of food insecurity}

Megan A. Carney ${ }^{1 凶}$ \& Keegan C. Krause ${ }^{2}$

\begin{abstract}
Global climate change and the continued neoliberalization of food systems have exacerbated levels of food insecurity and hunger, producing an ever-expanding population of displaced persons who are also nutritionally vulnerable. Restrictive immigration policies in post-arrival and resettlement contexts compound with other cultural, social, political, and economic conditions to negatively affect the food security and health of displaced persons. This article engages a comparative ethnographic perspective for examining the migration-food security nexus. Drawing on ethnographic research with Mexican and Central American im/migrants in the Western United States, Haitian im/migrants in the Dominican Republic, and African im/migrant populations in Italy, this article analyzes local experiences of food insecurity in restrictive immigration policy contexts through an intersectional lens. Finally, this article examines the possibilities for engaged research oriented toward generating "healthy publics" and addressing food insecurity across disparate geographical and political settings and amid structural and social constraints.
\end{abstract}

\footnotetext{
${ }^{1}$ School of Anthropology and Center for Regional Food Studies, University of Arizona, Tucson, AZ 85721, USA. ${ }^{2}$ Mel and Enid Zuckerman College of Public

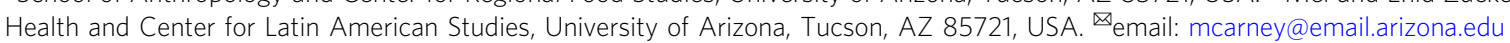




\section{Introduction}

$\mathrm{n}$ its most recent "State of Food Security and Nutrition in the World" report, the Food and Agriculture Organization of the United Nations estimated that more than 820 million people were experiencing chronic food insecurity or hunger. Food insecurity is defined by the FAO as prolonged lack of access to enough food to meet basic needs (FAO, 2019). Chronic food insecurity may lead to the physical, often painful sensation of hunger and to malnutrition (Messer and Cohen, 2007). Rather than simply a condition caused by insufficient economic means for purchasing food to meet adequate caloric intake, the experience of food insecurity is multidimensional and shaped by the complex interaction of multiple political, economic, and social factors (Pottier, 1999). Food insecurity alone is associated with a variety of physiological and mental health outcomes, including increased risk of metabolic disorders and heart disease (Gucciardi et al., 2009; Kirkpatrick and Tarasuk, 2008; Maynard et al., 2019; Vozoris and Tarasuk, 2003), as well as anxiety, depression, and increased stress (Martin et al., 2016; Muldoon et al., 2013; Olson, 1999; Slopen et al., 2010; Weaver and Hadley, 2009). Food insecurity on a global scale has precipitated widespread human displacement and migration (FAO, 2017a, 2017b, 2017c).

While the experience of food insecurity and its threats to human health and wellbeing often render migration a necessary strategy for survival, the food security and health of displaced and im/migrant populations are also often compromised in postarrival and resettlement contexts (Crush and Caesar, 2017; FAO, 2017a, 2017b, 2017c; Moffat et al., 2017). Food insecurity in the context of migration is often exacerbated by a lack of financial resources, language barriers, socially or culturally-specific food preferences, and limited knowledge of available resources and services (Anderson et al., 2014; Vahabi and Damba, 2013). The negative health outcomes associated with food insecurity may be amplified by im/migrants' experiences with chronic political insecurity, racialized stigma, and documentation precarity (Crocker, 2015; Gonzales and Chavez, 2012; Gonzales et al., 2013; Greenhalgh and Carney, 2014; Menjivar 2013; Salas et al., 2013; Viruell-Fuentes et al., 2012). Documentation precarity and economic constraints often act synergistically with food insecurity, propagating cyclical patterns of poor health in displaced populations that often rely on informal and unregulated employment and limited access to health care and social services (Carney, 2015a; Hadley et al., 2008; Mendenhall, 2012).

In this article, we engage a comparative ethnographic perspective for examining food insecurity as a significant barrier to "healthy publics" (Hinchliffe et al., 2018) in restrictive immigration or migration policy contexts. Following an explanation of our methodology, we present case studies from our respective field research sites: the Western United States, the Dominican Republic, and Italy. Recognizing the ways that food insecurity articulates with various aspects of im/migrant identity such as race, class, citizenship or legal status, gender, age, and (dis)ability, we employ an intersectional lens to analyze differential experiences and manifestations of food insecurity across our sites (Crenshaw, 1991: Mollet and Faria, 2013). In our discussion, we examine the possibilities for applying the healthy publics (Hinchliffe et al., 2018) concept to food-related displacement and food insecurity in post-arrival and resettlement contexts. Anthropologists in particular have insisted that policies and programs designed to ameliorate food insecurity should reflect and account for the lived experiences of communities that are most directly impacted (Garth, 2019; Pottier, 1999). By providing a more nuanced discussion of the ways that immigration policy contexts compound with other aspects of identity and structural constraints to shape lived experiences of migration and food insecurity, we seek to engage decision-makers, institutional actors within multilateral organizations, and others governing food and agricultural policy, immigration policy, health policy, economic development, and trade. Contrary to nativist and populist claims that immigration is a threat to public health, the enduring problem of food insecurity among im/migrant and displaced populations represents a formidable barrier to achieving healthy publics.

We employ "im/migrant" throughout this article to index the ways that there is much fluidity among the categories of immigrant, migrant, immigration, and migration. Empirical data have shown that people cite many different reasons for migrating or immigrating, and characterize their decisions by invoking myriad terms (Carney, 2015a; Castañeda, 2010; Zavella, 2011). While arguably imperfect, "im/migrant" serves as an inclusive referent for the populations we discuss in this article.

\section{The migration-food security nexus}

Neoliberal economic policies and climate-related events continue to displace millions from agrarian and pastoral livelihoods (FAO, 2017c; Nyantakyi-Frimpong and Kerr, 2017). The weakening of the welfare state brought about by neoliberal reforms such as structural adjustment programs, as well as the inability to compete with cheap agricultural imports rendered through multilateral trade agreements, have compromised the capacity of rural households around the world to avoid food insecurity (Carney, 2015a, 2017a, 2017b; Galvéz, 2018; Patel, 2007; Patel et al., 2009; Yates-Doerr, 2015). The influx of migrants heading to the United States following the North American Free Trade Agreement signed in 1994 by the United States, Mexico, and Canada, as well as the continued out-migration from African and Caribbean nations that underwent structural adjustment programs, serve as prime examples of the effects of trade liberalization and economic restructuring on rural, agrarian households (Cole and Groes, 2016; FAO, 2017a; Fernandez-Kelley and Massey, 2007; Galvéz, 2018; Pfeiffer and Chapman, 2010; Gros, 2010; Kay, 2006; Weeks, 1995). Climate change is already exacerbating current food insecurity trends through "increasing temperatures, changing precipitation patterns, and greater frequency of extreme events" (IPCC, 2019, p. 5). Impediments or interferences to food production include drought and desertification (particularly in the Mediterranean region and sub-Saharan Africa), extreme weather events, pests, crop disease, and lower nutritional quality of crops from higher atmospheric levels of $\mathrm{CO} 2$. These changes threaten the nearly 200 million people for whom the current food system provides a basic livelihood (IPCC, 2019). The UN Intergovernmental Panel on Climate Change in its Special Report on Climate Change and Land (2019) predicts heightened "environmentally induced migration both within countries and across borders" ( $\mathrm{p}$. 17) from disrupted food chains and threats to land-based livelihoods.

Scholars of globalization have identified a central contradiction of neoliberal capitalism-namely, that capital and commodities move freely across geopolitical borders while human mobility is restrained (Harvey, 2005). A "biopolitics of food insecurity" perspective underscores how food, in its commodity form and as a site of capital accumulation, moves across geopolitical borders while an ever-growing segment of the human population suffers from chronic food deprivation (Carney, 2014a, 2015a; Nally, 2011). In an arrangement described by Pechlaner and Otero (2010) as the "neoliberal food regime", corporate monopolization of the global food system is predicated on prioritizing profits and increasing returns for shareholders (McMichael, 2009; Nally, 2011). The global reach of this arrangement continues to displace millions from rural agrarian livelihoods who must then migrate as 
a means to find economic alternatives and to alleviate food insecurity, indexing the bidirectional bind through which people depend on the capacity of local and global food systems in order to meet their nutritional needs (Crush and Caesar, 2017). Crush and Caesar (2017) frame these dynamics as the "migration-food security nexus".

While documented or undocumented status alone is not the sole determinant of individual or group vulnerability to food insecurity, im/migrants of precarious legal status-i.e., undocumented and/or unauthorized-encounter additional barriers to accessing adequate food as forms of public assistance are often restricted to citizens and legal residents (Carney, 2015a, 2015b; Mares, 2019; Minkoff-Zern, 2019; Munger et al., 2015; Walsemann et al., 2017). Legal status often compounds with other variables such as race, class, gender, age, and (dis)ability to exacerbate food insecurity. When interacting with other risk factors such as poverty, immigration status, social isolation, and severe stress, food insecurity portends negative health outcomes (Carney, 2015a, 2015b; Greenwald and Zajfen, 2015; Kasper et al., 2000; Quandt et al., 2006; Vahabi et al., 2011). Yet even for im/ migrants with current and legally valid documents, the backdrop of nationalist immigration policies and broader immigration enforcement practices generates experiences with stigma and social isolation already familiar to those with precarious legal status (Chavez, 2013; Salas et al., 2013)

In a recent scoping review of the literature on "food insecurity among immigrant populations in high-income nations" (p. 376), Maynard et al. (2019) concluded by calling for more "in-depth qualitative research" on this subject. The migration-food security nexus thus warrants further scholarly attention, particularly by those seeking to do applied and engaged work.

\section{Methodology}

Both of us have been engaged in long-term ethnographic fieldwork at our respective research sites-Western United States and Italy (see especially Carney, 2013, 2014a, 2014b, 2015a, 2015b, 2015c, 2017a, 2017b), and the Dominican Republic (Krause)-for several years. By and large, our experiences as researchers have been with recently arrived im/migrants, mixed-status households, and the social actors and institutions providing various forms of support to these groups. We draw on our experiences as ethnographers to present and discuss the case studies featured in this article. We focus explicitly on recently arrived im/migrantsmany of whom have fled conditions of food insecurity in their communities of origin-and their experiences with food insecurity post-arrival.

Data for the first case study, i.e., Mexican and Central American im/migrant experiences with food insecurity in the Western United States, are derived from 20 months of ethnographic fieldwork that Carney conducted between 2008 and 2011 with $\mathrm{im} /$ migrant women $(n=25)$ and private food assistance programs operating in Santa Barbara County, California. At the time of this research, Santa Barbara County had one of the highest rates of food insecurity (39\% of low-income households) in the state of California (California Health Interview Survey, 2009) and in 2011, the county's leading hunger-relief organization reported that more than one-quarter of local residents had sought emergency food assistance. Although food insecurity is a complex problem, Santa Barbara County's high cost of living and relatively low-paying jobs in service and hospitality, construction, and agriculture, exacerbate this problem. Poverty in the region had been gradually increasing in recent years; as of 2010, one in five Santa Barbara County households and one in four children lived at or below the federal poverty level (US Census, 2011). Carney conducted outreach and recruited key informants through established community organizations in Santa Barbara County which were regularly frequented by local im/migrant communities, including private food assistance programs, community centers, and Head Start preschools. Local promotoras (community health workers) also assisted with publicizing the project and recruiting participants. Criteria for screening key informants included women of age 18 or older who had migrated from Mexico or Central America and had previous experience utilizing some form of food assistance. Participants ranged in age from 24 to 60 years (mean age of 38) and originated from Mexico, Honduras, and Guatemala, although the majority of women were from common sending states in Mexico such as Guerrero, Michoacán, and Oaxaca. Five of the women had obtained formal status in the US, including a woman from Guatemala who had been granted asylum, but most (20 out of 25 ) were "sin papeles" (i.e., undocumented). Women's length of residency in the US spanned from as short as three months to as long as 30 years. Semi-structured and life history interviews, dietary surveys, the USDA Household Food Security Scale, participant observation, and focus groups served as the primary instruments of data collection. As a participant-observer, Carney documented interactions between staff and volunteers of NGOs with im/migrant women and she accompanied key informants in their daily activities such as grocery shopping, informal work, picking up kids from school, and preparing meals.

The second case study draws on Krause's fieldwork in the informal tourism sector of the Dominican Republic. While the formal ethnographic and epidemiological data were collected during exploratory research in the summer of 2018 and three months of fieldwork in the summer of 2019, Krause also draws from nearly 3 years of prior professional experience living in the Dominican Republic working in the public education and health sectors, as well as time engaging in language and apiculture studies in rural Haiti in 2010. Krause's research conducted in 2019 utilized mixed methods, including participant observation, a cross-sectional occupational health survey, and semi-structured qualitative interviews to engage young Haitian and Dominican men ages 18 to 30 working in the informal tourism sector. His project explored experiences of young Haitian men with occupational health, access to social capital, and food security in the context of migration and structural and racialized violence. Krause's cross-sectional survey design adapted portions of the Center for Disease Control's National Institute for Occupational Safety and Health's Quality of Work Life Survey (CDC, 2010) and the Latin American and Caribbean Food Security Scale (Comité Cientifico de la ELCSA, 2012). Partnering with a local NGO, a Dominico-Haitian educator and two young Haitian men working in the informal tourism sector, the survey was culturally and linguistically adapted into Spanish and Haitian Kreyol. Krause completed the cross-sectional survey with Haitians $(n=31)$ and Dominicans $(n=29)$ working in the informal sector of two Dominican tourist hubs. Krause subsequently followed-up with 9 of the Haitian survey participants to complete semi-structured qualitative interviews, expanding on some of the reported survey data. Practicing participant observation, Krause spent time in the occupational and home settings with his participants, documenting interactions between young Haitian men and their coworkers, supervisors, tourists, taxi-drivers, shop attendants, and police, with a particular emphasis on racialized exposures and cultivation of social capital related to daily survival.

The third case study presents data from Carney's ethnographic fieldwork on migrant reception in Sicily that she began in 2014, building on previous research experience in Italy that she conducted in 2003, 2005, and 2008. Although food insecurity was not the primary focus of her research in Sicily, migrants' struggles with food surfaced and resurfaced as significant themes during 
her years of fieldwork. Beginning with the Arab Spring in 2011, migration across the Central Mediterranean into Europe surged, provoking declarations of a "refugee crisis" by European officials. In the peak years of this migration, between 2014 and 2017, an estimated 624,747 migrants arrived to Italy, primarily through Sicily, while "13,457 were lost along the way to its shores" (Fiore and Ialongo, 2018, p. 482). Based on records maintained by the Italian Ministry of the Interior, the majority of those arriving were seeking asylum and had begun their journeys from countries in Africa and the Middle East. As of mid-2019, 29 percent of Italy's asylum-seekers were residing in Sicily (down from 40 percent in 2018) (Osservatorio Migrazioni, 2018). Italy's Ministry of Interior reports that between 2011 and 2015, Sicily "was the region hosting the highest number of migrants seeking asylum and humanitarian protection" (IOM, 2018; Osservatorio Migrazione, 2018). According to the Italian National Institute for Statistics, more than half of Sicily's population was "at risk for poverty" in 2016, almost double the national average (23.1 percent) (EURES, 2019; ISTAT, 2016). In the same year, unemployment in Sicily was 22 percent compared with 11 percent in central and northern Italy, and youth unemployment was at a record high with estimates hovering around 50 percent (ISTAT, 2016). Carney obtained data for this project through participant observation at NGOs and grassroots organizations providing a range of services to migrants; migrant boat disembarkations; migrant reception centers for adults and also minors; offices of social workers; public protests and demonstrations; film screenings and art exhibitions focused on migration and human rights; migrant health clinics; restaurants and cafes promoting community-building around fusion cuisines; fundraisers to support humanitarian organizations engaged in some aspect of migrant reception; and conferences focused on ameliorating migrant reception conditions. She also conducted more than 100 semi-structured and informal interviews with migrants, social workers, Italian officials and authorities, volunteers for charitable and humanitarian organizations, clinicians, medical interpreters, members of the clergy, attorneys, university professors, students, business owners, and grassroots organizers.

These studies received human subjects approval from review boards at the University of California-Santa Barbara, University of Arizona, and Arizona State University. Informed consent was obtained from all participants.

In this article, we engage a comparative ethnographic framework for its potential to enhance our understanding of the broader context of the migration-food security nexus through honing theoretical models and challenging existing conceptual categories (Abramson and Gong, 2020; Simmons and Smith, 2019). This framework requires that we compare the effects of geographic location, environmental/occupational conditions, local policies, availability of public resources, and other community-level factors in rendering food insecurity and im/ migrants' lived experiences. Food insecurity across different populations and disparate ethnographic settings assumes myriad forms and meanings that must be accounted for in future research and policy (Pottier, 1999). An important aspect of our respective research projects has been an enduring commitment to engaged and collaborative research that will yield broad social impacts (Hinchliffe et al., 2018).

One limitation of this article is that we do not have ethnographic data to share from im/migrants' communities of origin. Another limitation is that we do not account for the experiences of children of im/migrants or of subsequent generations who have been excluded from obtaining citizenship because of laws governing the terms of formal belonging (e.g., jus sanguinis laws in Italy and TC/0168/13 in the Dominican Republic). Outside the scope of this article is examining the vast body of research on changes to and meanings of food practices among im/ migrant populations in resettlement contexts and the role of remittances in supporting food security in communities of origin.

\section{Case studies: food insecurity in restrictive immigration policy contexts}

Ensuring "los Básicos" (the Basics): Mexican and Central American Im/migrants in the United States. Since the late 1970s women have migrated from Mexico to the United States in more or less equal numbers to men, and much of this migration is unauthorized (Segura and Zavella, 2007). Food insecurity has increasingly underpinned migration from Mexico and Central America to the United States, and especially of women and children (Carney, 2015a, 2017a; Galvéz, 2018).

Estimates of the number of undocumented individuals living in the United States range between 10 and 11 million, representing about 3.5 percent of the national population (Passel and Cohn, 2011).

The post-9/11 environment of border militarization and securitization in the United States intensified extant restrictive immigration policies and practices of political exclusion as these applied to im/migrants. As summarized by the Migration Policy Institute (2011):

In the decade since 9/11, immigration policy has been viewed principally through the lens of national security, a development that has given rise to major new border security and law enforcement initiatives, heightened visa controls and screening of international travelers and wouldbe immigrants, the collection and storage of information in vast new interoperable databases used by law enforcement and intelligence agencies, and the use of state and local law enforcement as force multipliers in immigration enforcement.

Specific policies that restricted mobility of im/migrants both arriving to the United States vis-a-vis its border with Mexico and living within the country already have included the US Border Patrol's practice of "prevention through deterrence" (De León, 2015), the Department of Homeland Security's "Secure Communities" program through which local law enforcement conspire with federal Immigration and Customs Enforcement officials, and the expansion and entrenchment of privatized immigrant detention and mass deportations in the United States corresponding to a "racialized removal program" (Golash-Boza and Hondagneau, 2013). The cumulation of these punitive actions, referred to by some scholars as an "amplified immigration regime" (Menjívar, 2012), have provoked widespread fear and anxiety among im/migrant communities regarding the threat of apprehension, racial profiling, detention, and deportation.

At the time of Carney's research, California had the largest number of unauthorized im/migrants employed in its economy (US Census Bureau, 2010; Van Hook et al., 2005). As a factor of their status, undocumented im/migrants are excluded from most forms of public assistance. The Personal Responsibility and Work Opportunity Reconciliation (PRWORA) Act of 1996 for instance, barred foreign-born immigrants from being able to utilize federal welfare programs. Noncitizens and the children of noncitizens were found to experience more persistent and higher levels of food insecurity following the enactment of PRWORA (Van Hook and Balistreri, 2006). In her work on food insecurity among Latinx immigrants in Seattle, Washington, anthropologist Teresa Mares (2013) observes how: "Undocumented workers are helping to uphold the tattered safety net of 
public benefits even as they are denied access to these same benefits" (p. 5).

Santa Barbara County-located approximately 100 miles northwest of the city of Los Angeles-has a long history of labor migration from Mexico and was a major stronghold of Chicano culture following California's annexation from Mexico in 1848. Today, Latinx account for more than 40 percent of the local population (out of a total of 423,895), and many households identify Spanish as a first language (US Census 2010). Tourism, commercial agriculture, and construction rank among the region's principal economic activities, employing several thousand im/migrants annually for work as hotel housekeepers, janitors, cooks, gardeners, farmworkers, and construction workers. During the time of Carney's research, Latinx households accounted for 69 percent of total Santa Barbara County households in poverty (Bureau of Population Statistics, 2010).

Women in Carney's research explained that price was the ultimate determinant in purchasing decisions: "price comes first, you always go for the items on special" (Maya, age 26, from Guerrero) (all names herein are pseudonyms). Consistent with unprecedented increases in global food prices during recent years (Mittal, 2009), Olivia recalled a moment when rice, a central staple for her household, was unobtainable: "people are worried when prices go up. Because when food prices increase, like rice when it is scarce, and they see the prices increase by four or five dollars, this represents a real problem". Many in Carney's research admitted to reducing their food intake in the midst of these price increases, but explained that they always made sure to have enough of los básicos (basic foods): "we eat enough, but of basic things [básicos]"; "there is a lot of food even though it may not be nutritious. Like, there are many potatoes and this we use in many ways, in tacos, in tortillas, you can do a lot with these, so there is never a shortage of food".

Women in Carney's research often discussed comidas limitadas (limited foods, such as meat, fruit, and some vegetables), whose scarcity impeded efforts toward comida saludable (healthy meals). Women explained that limitada referred to the quality, rather than quantity, of food sources. Limitadas enhanced the nutritional value of básicos (basic foods). Brenda (age 56, from Cuernavaca) explained that básicos comprised the foundation of a nutritious diet but needed to be combined with limitadas for optimal health: "I think that tortillas, chiles, and beans are at the foundation of diet... and an egg or a piece of meat when things are going well." Conversely, many women perceived a persistent reliance on rice and beans, and in some cases, tortillas, bread, and milk, as inadequate for maintaining health. Concern that food would not last between paychecks compelled some women to ration foods with extra scrutiny: "it gives me much shame to be without food. One is always thinking of how to get what one needs for tomorrow. For example, if I buy a chicken, I always divide it in half, half for one day, half for the next day. So yes, one is worried that food will run out."

Food procurement in the context of limited economic resources could require many hours of investment, as women sought las especiales (bargains) through visiting multiple stores. Juliana (age 38, from Guerrero), for instance, preferred to plan her meals spontaneously around the best deals she could find. After walking her children to school each day, Juliana would begin her trip around town to survey prices at the stores within closest proximity to her home. She was always looking to aprovechar las especiales (take advantage of specials). Sometimes prior to her mid-morning walkabout, she would leaf through coupon books that had arrived in the mail. Knowing about the specials in advance could save her time, as without access to a car or someone to drive her, the journey between stores to compare prices was very time consuming. Yet only a handful of the women in Carney's research were able to engage in this type of price surveillance, as others were usually putting in the hours at wagebased sites of work. They described relying more on the practice of economizar (a verb translating as "to balance" or "to economize") to make the most of their purchases.

Mixed-status households, such as households with foreignborn parents and US-born children, were eligible for limited forms of public assistance such as the Special Supplemental Nutrition Program for Women, Infants, and Children (WIC) and the Supplemental Nutrition Assistance Program (SNAP). Yet women in Carney's research exhibited strong distrust of public assistance as they interpreted these programs at sites of state surveillance that could lead to their apprehension, detention, or deportation by US Immigration and Customs Enforcement (ICE) (see also Carney, 2015b). Low enrollment by undocumented individuals in public assistance is widely documented (Kaushal et al., 2014; Nam and Jung, 2008) and has been explained by the potential stigmas associated with participation (Kaiser, 2008) and the perceived risk of becoming a public charge when petitioning to the US government for formal status (this research preceded the reinstatement of the public charge rule by President Trump in 2020). Instead, women in Carney's research were more comfortable with seeking food assistance through private charities such as food banks and pantries.

Charitable forms of food assistance-increasingly assuming a larger share of the safety net since the mid-1980s when the US implemented sweeping budget cuts to federal welfare programs (Poppendieck, 1998)-were popular among all of the women in Carney's research. Yet due to the irregular hours and at-times inconvenient locations of programs, many women could not participate to reap their benefits. Despite women's occasional complaints about the disorderly process of distributions, or unfairness around how items were distributed among clients, they appreciated these sites for distributing staple items, and especially fresh produce. Moreover, women explained that they preferred these programs first and foremost for permitting them some degree of anonymity amid fears of state surveillance for those lacking formal status, as well as for offering a social outlet or opportunities to connect with other local forms of social support. Since the 2008 recession, however, demand for private food assistance in Santa Barbara County increased at an annual rate of 35 percent from 2008 to 2011 even amidst declining donations from government and corporate retailers (Foodbank of Santa Barbara County, 2012; Young, 2008). Other nonprofit organizations providing social services to im/migrants and low-income households throughout California also witnessed a halt in major streams of funding from major donors and governmental sources during the recession, thus compromising their ability to meet existing and growing need (personal communication with grants officer at the California Wellness Foundation).

"They are selling us the dream... but that dream is not real for us": Haitian Im/migrants working in the informal tourism sector of the Dominican Republic. The contemporary lived experiences of Haitian im/migrants in the Dominican Republic are rooted in centuries of colonialism and more recently, neoliberal economic reforms (Farmer, 1994, 2004; Howard, 2001; Sagás, 2000; Simmons, 2010; Tavernier, 2008). Once considered the most productive French colony of the "New World," Haiti is currently the poorest country in the western hemisphere with a GDP of 9.7 billion \$US (World Bank, 2019a) compared to the Dominican Republic's GDP of 81.3 billion \$US (World Bank, 2019b). Haiti also experiences severe income inequality, maintaining a high GINI coefficient (61 in 2012) and an estimated 70 to 80 percent of Haiti's population living at some level of poverty 
(PNUD, 2013). Haiti's extreme economic disadvantage is exacerbated by environmental precarity and constant political turmoil. The 2010 earthquake devastated Haiti's economy and infrastructure, killing well over 200,000 people and displacing an estimated one million more (CDC, 2014) while producing economic costs amounting close to the country's current GDP (Cavallo et al., 2010). A cholera outbreak reportedly prompted by poor hygienic practices of international aid workers put intense pressure on an already incapacitated healthcare system and claimed over 9000 Haitian lives (Frerichs, 2016). Haiti also receives an over-abundance of international food aid which has undermined the country's agricultural sector (Cohen, 2013; Kenny, 2011; Schuller, 2012; Zanotti, 2010). Most recently, a corruption scandal accusing President Jovenel Moise and his administration of embezzling billions of dollars earmarked for social spending resulted in the removal of government fuel subsidies in July of 2018 and subsequent mass protests and political turmoil that has continued well into 2020 (Chery, 2020; Human Rights Watch, 2020; Nugent, 2019).

Haiti's volatile political system and struggling economy is a driving force behind modern Haitian migration to the Dominican Republic's relatively more stable economy (Jayaram, 2010; Horst and Taylor, 2014). It is estimated that anywhere between 500,000 to $1,000,000$ Haitians live and work in the Dominican Republic today, and personal remittances received in Haiti make up an estimated 32 percent of Haiti's GDP (World Bank, 2019c).

Throughout the 20th century, Haitian im/migration to the Dominican Republic was largely facilitated by the rapid growth of the Dominican sugarcane industry. A binational bracero program and voluntary Haitian migration established a culture of labor migration while bolstering the Dominican economy (Jayaram, 2010). Sweeping neoliberal economic reforms and the overall decline of the Caribbean sugar industry in the 1990s and early 2000 s led to significant economic restructuring and the inevitable re-routing of Haitian im/migrant labor to other sectors of the Dominican economy. Today, global tourism and foreign direct investment are redefining the Dominican economy, drawing most Haitian im/migrants directly to tourist hubs and urban centers (Jayaram, 2010). In 2017, there were over six million tourist arrivals to the Dominican Republic, compared to the 470,000 tourists arriving in Haiti (World Bank, 2017). While many young Haitians aspire to fulfill their dreams of improved opportunity in the Dominican Republic's tourism sector, they are still subject to restrictive immigration policies and a political culture of hypernationalism and implicit and explicit racialized violence that lingers from the Trujillo dictatorship (1930-1961) and Balaguer regime (1960-1962; 1966-1978; 1986-1996). These legacies of structural and racialized violence still inform modern politics which undermine the potential for formal employment opportunities for most Haitians (Jayaram, 2010; Leventhal, 2013). In 2006, under President Leonel Fernández, the Dominican Republic also began to militarize its borders with the support of the United States (Miller, 2013). By 2009 the Haitian-Dominican border was patrolled by multimillion dollar black-hawk helicopters and rifle-toting CESFRONT (Specialized Border Security Corps) agents who had also reportedly received training resources from US Customs and Border Patrol (Miller, 2013).

Shortly after Dominican border militarization and the presidential succession of Leonel Fernández by Danilo Medina in 2012, on September 23, 2013 the Constitutional Court of the Dominican Republic enacted resolution TC/0168/13. This resolution retroactively denied Dominican citizenship to anyone born in the Dominican Republic after 1929 who could not prove that at least one parent was of Dominican nationality, decidedly naming anyone not meeting this criterion as an undocumented transient worker (IACH, 2015). While harsh international responses pressured the Dominican government to re-evaluate, and offer a system for Dominican-Born Haitians to apply for proper documentation, the process is slow and the rhetoric this edict produced has lingered, producing certain precarity for Haitians with and without documentation as militarized immigration enforcement seems to take their cues from the current United States presidential administration. Subsequently, Haitian im/migrants frequently rely on informal (licit or illicit) and unregulated employment (Leventhal, 2013).

In his ethnographic work, Krause found that young Haitian men most often engage in the informal tourism sector in positions which can be broadly defined as either local business promotion promoting local restaurants, clubs, or aquatic activities or ambulatory entrepreneurship, selling fruits, peanuts, sunglasses and phone cases on the streets and beaches. Those working in promotion usually earn between 5 to 20 percent of their daily sales, being paid nearly always under the table without formal contracts. Haitians living and working in this setting often speak several languages; in addition to Haitian Kreyol and French, many speak nearly fluent Spanish and English. Their linguistic competencies and sometimes precarious documentation status are often capitalized on by Dominican and foreign business owners. A walk through many Dominican tourist hubs will prove that a significant portion of those initiating contact with potential patrons are Haitian. Many Haitians also capitalize on these skills through copious interactions with foreign tourists, often building lasting relationships resulting in tremendous social capital not otherwise available in Haiti or through relationships with their Dominican counterparts. For example, one young Haitian man working as a restaurant promotor on the beach often spends what little free time he has volunteering as a translator and cultural liaison for international medical missions in nearby communities. While not formally compensated for his time, he has been able to form meaningful and lasting relationships with some of the United States and Canadian medical professionals. This young man's newly established global social capital eventually manifested in these volunteers crowd-sourcing financial support in order to cover the costs of a new student visa and inscription fees, allowing him to enroll at the Dominican Republic's flagship university to study tourism and management.

While the life histories of these young Haitian men were diverse and complex, they all shared similar experiences with food insecurity and stress. Of the young Haitian men who participated in the survey only 10 percent reported being able to cover all or most of their living expenses with current wages, while 65 percent and 81 percent, respectively, reported worrying about running out of food and had actually run out of food in the last three months. Furthermore, 77 percent of young Haitian men report having to eat the same food nearly almost every day due to lack of funds and access to diverse and affordable nutritional options. Most young men attributed these experiences to geographic isolation due to racialized stigma and a lack of readily available resources.

The intersection of poverty, racialized violence and stigma, and food insecurity can be a vicious cycle, especially when tethered directly to the globalized tourism economy. As a young Haitian restaurant promoter explained to me in English, "They are selling us the dream, and we are supposed to sell that dream too. But that dream is not real. It isn't real for us," referring to the dream of "paradise" that the local business owners leverage while encouraging Haitians to work in the informal sector for low wages at the beach, and the dream that these same young Haitians are expected to sell to tourists. This dream indeed is highly implausible for those engaging in the informal sector, who often cannot afford to live in the high-priced tourist communities in which they work (also see Brennan, 2004; Padilla, 2008), 
necessitating significant expenditure on daily transportation. Those who are able to live near tourism sites are relegated to slum-like conditions with intermittent access to electricity and potable water. For Haitians, this situation can be exacerbated by precarious documentation status and intermittent crack-downs by the national police, which can be risky for Haitians regardless of documentation status. Many young Haitian men report difficulties obtaining secure housing agreements and being isolated to their work at the beach and to their homes due to enhanced policing: "It is a terrible cycle... I go to the beach, and I go home, that's it... Sometimes they give me food for lunch (the restaurant), if not, I eat in the street (buying food from street vendors) or don't eat... but I don't spend time in the street because it isn't safe" (Haitian restaurant promotor).

While nearly all communities have at least some access to rice, oil, some fresh vegetables and eggs through local colmados (food stands/shops), most of these young men lack utilities to cook or keep perishable items. Consequently, they must rely on purchasing food from streetvendors, or the generosity of neighbors. While street food is relatively cheap, it is much more expensive and less nutritious than having control of diverse ingredients in one's own kitchen. One of the young Haitian men explained to me further, that if someone is fortunate enough to work at a restaurant, they can potentially eat a meal or two before or after work due to the occasional generosity of their employers. However, when rumblings of immigration raids surface, which increased significantly in June of 2019 (Dominican Today, 2019), fear of being arrested or harassed means staying isolated, skipping work, and losing out on that day's wages while also missing the potential free meals consumed while at work. This inconsistent work presence may mean increased chances of being fired from one's informal position, resulting in more financial precarity and food insecurity. When asked about what young Haitian im/ migrant men need to survive while living and working in this precarious setting, some said increased access to basic resources, but many young men explained that what they would prefer, are structural changes to produce better opportunities: "I just need one thing right now, that thing is called opportunity. I don't want someone to come and give me a big plate of food every day. I don't want you to do things for me, I just want the opportunity to do it myself... and I don't mean from just one person, you know? I need my nation, my community, my society to give me what we call opportunity," (Haitian beach worker).

\footnotetext{
"A system based on a logic of 'emergency": African Im/ migrants in Italy. Decades of structural adjustment programs and, more recently, increased climatic stress on local environments throughout much of the African continent, have contributed to civil war and violence, widespread displacement from agrarian and pastoral livelihoods, and internal and transnational migration (Cole and Groes, 2016). These conditions precede increased migration from North Africa through the Central Mediterranean. This migration is what the EU deems as "clandestine" and has tried to prevent through border militarization, surveillance, and third-country agreements, even though the vast majority of those coming across the Mediterranean by unseaworthy sea vessels are seeking asylum (De Genova, 2017).

In 2017, the most reported countries of origin during disembarkations at Italian ports were Nigeria $(18,158$ or 15 percent), Guinea (9701 8 percent), and Côte d'Ivoire (9507 8 percent) (Osservatorio Migrazione 2018). As explained by a Palermo-based nonprofit volunteer who regularly helped migrants to complete their asylum paperwork, increased migration from the African continent in recent years could be attributed to "The situation in their countries: wars and conflicts
}

that have created myriad challenges, so much so that they cannot make lives for themselves. There is no work. They are seeking a better life." Reasons listed for seeking asylum and relayed to social workers and local authorities with whom Carney spoke to between 2014 and 2017 included forced military conscription (Eritrea), violence and civil unrest (Libya, Egypt, Tunisia, Nigeria, Guinea), and civil war (Côte d'Ivoire). While any person was eligible to apply for asylum upon setting foot for the first time in EU territory, many of these arriving asylum-seekers viewed Italy as a "transit country". Given terms in the Dublin Regulation that restrict movement by asylum-seekers between EU countries until their asylum paperwork has been processed and approved, many asylum-seekers were preferring to remain undetected by authorities while in Italy and therefore maintained their status as irregolari (irregular or undocumented im/migrants). Ambiguities in Italy's immigration laws, as well as changes to the criteria for granting international protection implemented by former Interior Minister Matteo Salvini in 2018 have rendered a record 670,000 irregolari (irregular, i.e., undocumented im/migrants) in Italy, representing about 1 percent of the national population (Vita, 2019). These individuals encounter myriad constraints on housing and employment and are barred from accessing a variety of public services.

Often deemed a "latecomer" to matters of immigration in comparison with much of Western Europe, Italy did not introduce its first legislation dealing with immigration until the late 1980s (no. 943, 30 December 1986) (Zincone, 2006). Italy's immigrant population has gradually grown from around 300,000 in the 1980s to nearly 5 million in the mid 2010s (Degiuli, 2016). Varying with economic conditions and labor shortages, Italy has implemented a mix of restrictive and more welcoming immigration policies (Degiuli, 2016). The Bossi-Fini law that once criminalized Italian citizens who assisted irregolari, recalled by one of Carney's informants as "a policy that prohibited hospitals from caring for migrants without documents and put doctors and nurses at risk of imprisonment," as well as the more recent Decreto Sicurezza (Security Decree) introduced by Matteo Salvini serve as prominent examples of restrictive immigration policies that have gone into effect in the past two decades. Degiuli (2016) explains that Italian immigration laws frequently tether legal status to ensuring "a cheap and flexible workforce" (p. 48). Italy's Istituto nazionale della previdenza sociale (INPS)-Italy's public retirement system-which collects data on workers, reported in 2018 that nearly 70,000 im/migrants were formally employed in Sicily's agricultural and fishing sectors (38 percent), and as domestic workers (30 percent) (Osservatorio Migrazione 2018). Meanwhile almost the same number of im/migrants were unemployed or underemployed as "flessibilità" (flexible) workers (Osservatorio Migrazione 2018). As stated by one social worker that Carney interviewed in Palermo in 2016, and reiterated on various occasions by others with direct experience assisting im/ migrants, "They take the hardest jobs, that in part also uphold Italy's welfare system. They are the only ones who are willing to work as janitors, domestics, service workers. They are completely exploited."

As a factor of Italian laws that tether work to legal status, many employers require that im/migrants present proof of residence prior to extending work contracts. As summarized to Carney by a cultural mediator working inside one of Sicily's migrant reception centers: "The problem is that migrants don't always find work because many Italians don't have much trust in them. But then, without a job, a migrant cannot apply for a residency permit. It's like a dog who bites his own tail: without a residency permit, one cannot find a job." An Italian journalist who also worked periodically in special operations with the Italian military shared with Carney, "For the most part, the people who we receive here 
in Italy, after a year, or two or three, they find themselves of 'irregular' status, without documents, leaving the country or working in the black market. It is a situation completely out of control, owing to the fact that it is a system based on a logic of 'emergency' rather than long-term solutions."

Charitable and faith-based organizations attempt to fill in gaps in the safety net for irregolari. However, these organizations have witnessed dwindling donations and sources of monetary support in the years following the 2008 sovereign debt crisis and the economic austerity measures that ensued shortly thereafter. Moreover, organizations have been coping with these structural shifts as they also respond to heightened demand for their services by citizens and noncitizens (Carney, 2017b; see also Loopstra et al., 2015). One such organization where Carney visited for her fieldwork is Table of Solidarity (Mensa della Solidarietà), a faith-based soup kitchen in the town of Agrigento on Sicily's southern coast. Social workers from the local Caritas chapter regularly referred migrants to the daily breakfast and lunch services offered by Table of Solidarity. Each time she arrived to Table of Solidarity, Carney counted nearly 100 people or more waiting outside for a meal. When meals were ready, clients entered the expansive dining room to assume a place at one of the long cafeteria-style tables. Activities at the soup kitchen were overseen by Sister Maria Stella, a woman whose boisterous energy, petite frame, and gentle, almost childlike voice imparted her an aura of eternal youthfulness, even at her 60-something years of age.

On her first day at Table of Solidarity, Sister Maria Stella led Carney on a tour of the soup kitchen's dining hall and commercial kitchen. Several volunteers, donning white aprons and gloves, were wrapping up their activities in the kitchen and preparing to serve clients. That day's menu was undeniably one of the more elaborate that Carney had encountered at similar food assistance programs in Sicily: risotto di mare (seafood risotto), sautéed carrots, grilled sardines, and a gelatin of salmon. While clients retrieved trays of food from the service window, Sister Maria Stella circled the room to socialize. Carney's conversations with volunteers - most of them agrigenti (from the Sicilian region of Agrigento) - revealed that they were pensionati (retired and receiving pensions) and had been helping at the soup kitchen for several years. Some of them volunteered daily, while others restricted themselves to one or two days per week. In his discussion of volunteerism in Italy, Nicola Maggini, (2018) alludes to how "In the absence of a strong and universal welfare state, the family and Catholic-run charity services remain the strongest safety nets," (p. 111).

As Carney observed primarily in the coastal regions of Palermo and Agrigento, charitable organizations like Table of Solidarity operated soup kitchens and food pantries during a set number of hours on weekday mornings and afternoons. Most operations were closed on weekends. Yet, provisions offered at food pantries were often unusable for migrants without access to housing, refrigeration, or cooking facilities, such as those who were camping outside one of Sicily's train stations or squatting in abandoned buildings. Social workers Carney interviewed also alluded to how the location and hours of migrants' limited, and often seasonal work opportunities in agriculture and construction, impeded them from accessing soup kitchens and food pantries in the morning or the middle of the day. Those who struggled to utilize these programs alluded to surviving on the cheapest food they could find, as one young man stated in explaining his predicament, "There's bread, and more bread." Recognizing the needs of migrants who were having to prioritize work when such opportunities arose, volunteers with NGOs and grassroots groups distributed sandwiches and bottles of water to temporary encampments where migrants were residing.

\section{Discussion: addressing food insecurity as a matter of healthy publics}

These case studies provide irrefutable evidence of the ways that current global political-economic arrangements and restrictive immigration policies complicate the migration-food security nexus. Across our case studies-Mexican and Central American $\mathrm{im} /$ migration to the United States, Haitian im/migration to the Dominican Republic, and African im/migration to Italy-the experience of food insecurity was compounded by a matrix of variables, sometimes but not always including precarious legal status (Santa Barbara, Dominican Republic, and Italy), expensive (Santa Barbara) or insecure housing (Dominican Republic and Italy), under-employment or unemployment, and eroding safety nets. Reliance on public assistance and safety nets as a wholeparticularly in the United States and Italy-was tenuous at best. Public and private programs in both settings have been coping with fewer resources at their disposal while also responding to rising demand for food assistance as working families struggle to earn living wages (Dickinson, 2019; Muehlebach, 2012; Reese, 2019). Policies that restrict use of public assistance according to one's legal status related to nativist anxieties about the "threats" posed by im/migrants to the population and resources within a territory (also see Chavez, 2013; Menjívar, 2012; Simmons, 2010; Ticktin, 2011; Zavella, 2011). In the Dominican Republic, neoliberal and nativist driven policies interact synergistically with the globalized tourism economy, both drawing in Haitian im/ migrants to a competitive global market while isolating them from basic resources. A "healthy publics" framework (Hinchliffe et al., 2018) could be very promising for addressing food insecurity among im/migrant populations, but first we need to reconcile with some significant barriers to enacting such a framework.

Structural and social barriers to engaged research: culprits of an ontological impossibility. Stephen Hinchliffe and colleagues (2018) have introduced the concept of "healthy publics" to reference the "dynamic collectives of people, ideas and environments that can enable health and wellbeing" (p. 2). They emphasize the potential of this concept in stimulating collaborations around engaged research. Healthy publics may encompass both the collectives that assemble around research seeking to transform health and wellbeing, and the relationships and formations that are constituted through or emerge as an outcome of such collectives. Hinchliffe et al. (2018) are forthcoming in stating how "emergent and collective approaches to redefining, creating and sustaining healthy publics requires considerable time, resources and work" (p. 5) particularly for those unaccustomed to doing research.

We should not discount the formidable barriers that may prevent im/migrant populations from participating in engaged research. As both sites of reproduction and subversion of state practices, universities and their affiliates are often perceived as threats to im/migrant households and communities-especially to individuals of precarious legal status-rather than as spaces of sanctuary (Carney et al., 2017). We feel implored to ask then, what are the implications of these structural arrangements and institutional practices for applying a healthy publics framework to addressing food insecurity in restrictive immigration policy contexts? Can we imagine such an application, or is it at present an ontological impossibility? How might an engaged research agenda in this case require that we as researchers first (partially) dis-engage from the grips of state institutions?

As we have observed firsthand in cultivating a regional network of community-based collaborators to partner on food and health research in the southern Arizona-Sonora borderlands food 
system (see Carney and Krause, 2019a, 2019b), collectively engaged research can be an equally messy and rewarding process. While our particular work in this setting does not respond to or explicitly engage im/migrants and their experiences with food insecurity as we outlined in our case studies, we feel it is nonetheless germane to discussions about the potential for galvanizing or constituting healthy publics around the issue of food insecurity and through an engaged research process.

Despite the laudable intentions of those seeking to perform engaged research, the path to enacting an engaged research agenda is more often than not riddled with structural and social barriers. Structural barriers stem from academic institutions and organizations that provide funding for research. Within these settings, there is a tendency to devalue engaged research through questioning its scientific objectivity. Researchers are not always successful in their attempts to secure funding from highly reputable grant-making organizations, sometimes yielding negative consequences for their career trajectories. Promotion and tenure as institutionalized processes reward individuals based on their success to secure funding from prestigious institutions and publish and present in peerreviewed journals. Yet because of the institutionalized norms that dismiss engaged research as less scientifically rigorous, there are barriers to publishing on such work in peer-reviewed journals. At present, many academic institutions and funding organizations, at least from our experience in the United States, are not structured to support more individuals and groups pursuing socially engaged research.

Social barriers to conducting engaged research revolve around communities that have been historically exploited or marginalized in research contexts, and for whom "research" itself can be a dirty term. That research has done harm to its human subjects is not a reality that can simply be undone, and the particularities of this problem take on different forms across academic disciplines. In anthropology for instance, a discipline that has an admittedly fraught history in terms of its role in statecraft, extractivist practices, and "salvage paradigms," we emphasize building rapport and trust as essential to the foundation of our relationships with research collaborators (Reardon and TallBear, 2012). Trust is not merely a currency for accessing locally-specific knowledge; it also binds us to the struggles of our collaborators in indelible ways (Perry, 2009, 2014).

If healthy publics and engaged research are tethered to one another, a research agenda for healthy publics is not possible without addressing or at least reckoning with the structural and social barriers that hinder broader adoption and implementation of engaged research methods. The ways that these barriers operate to preclude certain modes of inquiry from being formally recognized might index the existence of an ontological impossibility. The process of dismantling these barriers will likely require new lexicons, ontologies, and epistemologies, the implications of which could (and perhaps should) include an identity crisis within academia. Although knowledge production has always arguably been in service to a broader public, it is debatable the extent to which many academics view themselves as public servants. Academic institutions are by no means immune to the effects of neoliberalization; indeed, they are increasingly instrumental to the entrenchment of neoliberal ideology in our political, economic, social, and healthcare systems (Boggs and Mitchell, 2018; Giroux, 2014; Hundle et al., 2019; Newfield, 2016; Shore and Wright, 1999). In this regard, a considerable segment of those in academia now serve private interests that are of course in contradistinction to, and very much undermine key traits of healthy publics, such as access to food as a universal right. It is possible that the sorts of changes we are seeking to implement with an engaged approach to research may not be achievable while working within the political economy, bureaucracy, and standards of evaluation within universities. In short, a healthy publics framework for doing research-on food insecurity or any other threat to public health-must engage a critical university studies framework as well to account for the ways that academic institutions themselves are implicated in the production of unhealthy publics (see Boggs and Mitchell, 2018; Hundle et al., 2019).

\section{Conclusion}

As a basic necessity of life, food is a most necessary foundation of healthy publics. For the millions of people displaced from their countries of origin today, we should be more cognizant of how food insecurity might explain their displacement. Despite the clear articulation of the human right to food in the International Covenant on Economic, Social, and Cultural Rights, rarely do states recognize food insecurity and hunger as legitimate explanations for seeking asylum (Chilton and Rose, 2009; Messer and Cohen, 2007). Moreover, refusal by many governments to accept responsibility for the devastating impacts of neoliberal economic policies on rural livelihoods and of capitalism for environmental degradation has translated to a bifurcation of policies dealing with migration and economic development (Patel, 2007; Patel et al., 2009). With climatic instability accelerating the rate of global environmental change, food crises and increased levels of human displacement are inevitable (FAO et al., 2018; Patel et al., 2009). It is imperative that governments of migrant-receiving countries anticipate food shortages and other threats to the food supply, as well as widespread human displacement through more integrated forms of policy-making.

One place to begin this shift in policy would be to revisit international accords governing procedures for asylum. Some may argue that asylum should be a fixed category restricted to those with legitimate fears of persecution because of race, religion, nationality, political opinion or membership in a particular social group (UNHCR, 2020). But governments have not seriously revisited international asylum law since 1951, in the aftermath of World War II (Hatton and Williamson, 2005). Countless policy experts and scholars have underscored how dramatic differences in today's population of global displaced persons require us to revise these global accords and overhaul what's included in the category of "asylum" (Rabben, 2016).

We should show compassion for those fleeing the very painful experiences of food insecurity and hunger. We need to adopt more humane asylum policies that recognize new threats and assume responsibility at the collective level. Engaged research collectives forming around and through a commitment to healthy publics can help to steer these necessary changes to policy at multiple scales, but we need to reconceptualize what the scholarly community categorizes as "research" and encourage processes of knowledge production that serve the interest(s) of collectives rather than individuals or singular institutions. As long as nativist anxieties continue to reign in the realm of immigration policy circles, and as global environmental change heightens the vulnerability of populations to displacement, then we will continue to witness record-level food insecurity and the expansion and entrenchment of unhealthy publics.

\section{Data availability}

Data sharing is not applicable as the privacy and safety of individuals could be compromised.

Received: 1 December 2019; Accepted: 9 April 2020;

Published online: 13 May 2020 


\section{References}

Abramson CM, Gong N (2020) Beyond the case: the logics and practices of comparative ethnography. Oxford University Press, Oxford

Anderson L, Hadzibegovic DS, Moseley JM et al. (2014) Household food insecurity shows associations with food intake, social support utilization and dietary change among refugee adult caregivers resettled in the United States. Ecol Food Nutr 53(3):312-332

Boggs A, Mitchell N (2018) Critical university studies and the crisis consensus. Feminist Stud 44(2):432-463

Brennan D (2004) What's love got to do with it? Transnational desires and sex tourism in the Dominican Republic. Duke University Press, Durham

Bureau of Population Statistics (2010) Profile of general demographic statistics. Bureau of Population Statistics

California Health Interview Survey (2009) California Health Interview Survey. http://www.chis.ucla.edu

Carney MA (2013) Border meals: detention center feeding practices, migrant subjectivity, and questions on trauma. J Food Cult 13(4):32-46. https://doi. org/10.1525/gfc.2013.13.4.32

Carney MA (2014a) The biopolitics of "food insecurity": towards a critical political ecology of the body in studies of women's transnational migration. J Political Ecol 21(1 A):1-18. https://doi.org/10.2458/v21i1.21123

Carney MA (2014b) 'You want to feed your family, don't you?' Exploring the consequences of economic crisis for everyday food practices in immigrant communities. Gender Sexuality Feminism 1(2). https://doi.org/10.3998/ gsf.12220332.0001.202

Carney MA (2015a) The unending hunger: tracing women and food insecurity across borders. University of California Press, Berkeley, Los Angeles

Carney MA (2015b) Eating and feeding at the margins of the state: barriers to healthcare for undocumented migrant women and the "Clinical" aspects of food assistance. Med Anthropol Q 29(2):196-215

Carney MA (2017a) "Back there we had nothing to eat": the case of transnational food insecurity. Int Migr 55(4):64-77. https://doi.org/10.1111/imig.12293

Carney MA (2017b) 'Sharing one's destiny': effects of austerity on migrant health provisioning in the mediterranean borderlands. Soc Sci Med 187:251-258. https://doi.org/10.1016/j.socscimed.2017.02.041

Carney MA (2020) Island of hope: migration and solidarity in the mediterranean. University of California Press, Berkeley, Los Angeles

Carney MA, Krause KC (2019a) State of the Tucson food system, 2018-2019. University of Arizona College of Social and Behavioral Sciences, Center for Regional Food Studies. https://crfs.arizona.edu/sites/crfs.arizona.edu/files/ CRFS-TucsonFoodSystems2018-Digital.pdf. Accessed 21 Nov 2019

Carney MA, Krause KC (2019b) Cultivating a network of citizen-scientists to track change in the Sonora-Arizona foodshed. J Agric Food Syst Community Dev 1-2. https://doi.org/10.5304/jafscd.2019.084.021

Carney MA, Gomez R, Mitchell K, Vannini S (2017) Sanctuary planet: a global sanctuary movement for the time of Trump. https://societyandspace.org/ 2017/05/16/sanctuary-planet-a-global-sanctuary-movement-for-the-time-oftrump/. Accessed 12 Nov 2019

Castañeda H (2010) Im/migration and health: conceptual, methodological, and theoretical propositions for applied anthropology. NAPA Bull 34(1):6-27

Cavallo F, Powell A, Becerra O (2010) Estimating the direct economic damages of the earthquake in Haiti. Economic J 120(546):F298-F312

CDC (2010) National assessment of occupational safety and health workforce. https://www.cdc.gov/niosh/oshworkforce/default.html. Accessed 4 Apr 2018

CDC (2014) Cholera in Haiti. https://www.cdc.gov/cholera/haiti/index.html. Accessed 18 Mar 2020

Chavez LR (2012) Undocumented immigrants and their use of medical services in Orange County, California. Soc Sci Med 74(6):887-893

Chavez LR (2013) The Latino threat: constructing immigrants, citizens and the nation. Stanford University Press, Stanford

Chery, D (2020) Haiti Protests by Police Erupt in Gunfire. The New York Times https://www.nytimes.com/2020/02/23/world/americas/haiti-protest-violence. html. Accessed 17 Mar 2020

Chilton M, Rose D (2009) A rights-based approach to food insecurity in the United States. Am J Public Health 99(7):1203-1211

Cohen MJ (2013) Diri Nasyonal ou Diri Miami? Food, agriculture US-Haiti relat food security 5(4):597-606

Cole J, Groes C (eds) (2016) Affective circuits: African migrations to Europe and the pursuit of social regeneration. The University of Chicago Press, Chicago

Comité cientifico de la ELCSA (2012) Escala Latinoamericana y Caribeña de Seguridad Alimentaria (ECLSA): Mannual De Uso y Aplicaciones. FAO, 2012 print, Roma

Crenshaw K (1991) Mapping the margins: intersectionality, identity politics, and violence against women of color. Stanf Law Rev 43(6):1241-1299

Crocker R (2015) Emotional testimonies: an ethnographic study of emotional suffering related to migration from Mexico to Arizona. Front Public Health $3: 177$
Crush J, Caesar M (2017) Introduction: cultivating the migration-food security nexus. Int Migr 55(4):10-17

Degiuli F (2016) Caring for a living: migrant women, aging citizens, and Italian families. Oxford University Press, Oxford

De Genova N (2017) Introduction: the borders of 'Europe' and the European question. In: Nicholas DeGenova (ed) The borders of "Europe": autonomy of migration, tactics of bordering. Duke University Press, Durham, p 1-35

De León J (2015) The land of open graves: living and dying on the migrant Trail. University of California Press, Berkeley, Los Angeles

Dickinson M (2019) Feeding the crisis: care and abandonment in America's food safety net. University of California Press, Berkeley, Los Angeles

Dominican Today (2019) Immigration deports 895 Haitians. https:// dominicantoday.com/dr/local/2019/09/24/immigration-deports-895haitians/. Accessed 5 Mar 2020

EURES (2019) Labour Market Information: Sicily. EURES: The European Job Mobility Portal. https://ec.europa.eu/eures/main.jsp?catId $=402 \&$ countryId $=I T \& a c r o=1 m i$ \&lang $=$ en\&regionId $=$ ITG\&nuts 2 Code $=$ ITG1 \&nuts3Code $=\&$ regionName $=S i-$ cilia. Accessed 17 Oct 2019

Farmer P (1994) The Uses of Haiti. Reprint. Common Courage Press, Monroe

Farmer P (2004) An anthropology of structural violence. Curr Anthropol 45 (3):305-325

FAO, IFAD, IOM, WFP (2018) The linkages between migration, agriculture, food security and rural development: Rome, Italy. www.fao.org/3/CA0922EN/ CA0922EN.pdf. Accessed 25 Nov 2019

FAO (2017a) Evidence on internal and international migration patterns in selected African countries: Rome, Italy. www.fao.org/3/a-i7468e.pdf. Accessed 25 Nov 2019

FAO (2017b) Forced migration and protracted crisis. A multilayered approach: Rome, Italy. www.fao.org/3/a-i7880e.pdf. Accessed 25 Nov 2019

FAO $(2017 \mathrm{c})$ Migration, agriculture and climate change. Reducing vulnerabilities and enhancing resilience: Rome, Italy. www.fao.org/3/I8297EN/i8297en.pdf. Accessed 25 Nov 2019

FAO (2019) The State of Food Security and Nutrition in the World: Safeguarding against economic slowdowns and downturns. http://www.fao.org/state-of food-security-nutrition/en/. Accessed 25 Nov 2019

Fernandez-Kelley P, Massey D (2007) "Borders for whom? The role of NAFTA in Mexico-U.S. Migration.” Ann Am Acad Political Soc Sci 610:98-118

Fiore T, Ialongo E (2018) Introduction: Italy and the Euro-Mediterranean 'migrant crisis': national reception, lived experiences, E.U. pressures. J Mod Ital Stud 23(4):481-489

Frerichs R (2016) Deadly river: cholera and cover-up in post-earthquake Haiti. Cornell University Press

Foodbank of Santa Barbara County (2012) Foodbank of Santa Barbara county. http://www.foodbanksbc.org

Galvéz A (2018) Eating NAFTA: trade, food policies, and the destruction of Mexico. University of California Press, Berkeley, Los Angeles

Garth H (2019) Food in Cuba: the pursuit of a decent meal. Stanford University Press, Stanford

Giroux H (2014) Neoliberalism's War on Higher Education. Haymarket Books

Golash-Boza T, Hondagneu-Sotelo P (2013) Latino immigrant men and the deportation crisis: a gendered racial removal program. Lat Stud 11 (3):271-292

Gonzales RG, Chavez LR (2012) "Awakening to a nightmare": abjectivity and illegality in the lives of undocumented 1.5- generation Latino immigrants in the United States. Curr Anthropol 53(3):255-281

Gonzales RG, Suarez-Orozco C, Dedios-Sanguineti MC (2013) No place to belong: contextualizing concepts of mental health among undocumented immigrant youth in the United States. Am Behav Scientist 57(8):1174-1199

Greenhalgh S, Carney MA (2014) Bad biocitizens?: Latinos and the US “obesity epidemic. Hum Organ 73(3):267-276. https://doi.org/10.17730/humo.73.3. w53hh1t413038240

Greenwald HP, Zajfen V (2015) Food insecurity and food resource utilization in an urban immigrant community. J Immigr Minority Health 19(1):179-186. https://doi.org/10.1007/s10903-015-0331-9

Gros J (2010) Ingestible recipe: Rice, chicken wings, and international financial institutions. J Black Stud 40(5):974-968

Gucciardi E, DeMelo M, Vogt JA et al. (2009) Exploration of the relationship between household food insecurity and diabetes in Canada. Diabetes 32 (12):2218-2224. https://doi.org/10.2337/dc09-0823

Hadley C, Galea S, Nandi V et al. (2008) Hunger and health among undocumented Mexican migrants in a US urban area. Public Health Nutr 11(2):151-158. https://doi.org/10.1017/S1368980007000407

Harvey D (2005) A brief history of neoliberalism. Oxford University Press, Oxford

Hatton TJ, Williamson JG (2005) Global migration and the world economy: two centuries of policy and performance. MIT Press, Cambridge

Hinchliffe S, Jackson MA, Wyatt K et al. (2018) Healthy publics: enabling cultures and environments for health. Pal Commun 4(1). https://doi.org/10.1057/ s41599-018-0113-9 
Howard D (2001) Coloring the nation: race and ethnicity in the Dominican Republic. Lynne Rienner, Boulder

Horst HA, Taylor EB (2014) The role of mobile phones in the mediation of border crossings: a study of Haiti and the Dominican Republic. Aust J Anthropol 25 (2):155-170

Human Rights Watch (2020) Haiti Events of 2019. Human Rights Watch. https:// www.hrw.org/world-report/2020/country-chapters/haiti: Accessed 18 Mar 2020

Hundle AK, Vang M, Alamri N, Deol A, Bermúdez D, Barton V, Cabrera G, Gutierrez B, Medina Maya C (2019) Thinking the "Twenty-First Century Neoliberal Research University: reflections on opportunity, risk, and solidarity at the New University of California. Crit Ethn Stud 5(1-2):174-204

Inter-American Commission on Human Rights (IACHR) (2015) Report on the situation of human rights in the Dominican Republic. ISBN 978-0-82706523-9

International Organization of Migration (IOM) (2018) Mediterranean migrant arrivals reached 171,635 in 2017; deaths reach 3,116. https://eea.iom.int/ mediterranean-migrant-arrivals-reached-171635-2017-deaths-reach-3116. Accessed 22 Jan 2020

IPCC (2019) UN Intergovernmental Panel on Climate Change in its Special Report on Climate Change and Land Panel on Climate Change in its Special Report on Climate Change and Land https://www.ipcc.ch/site/assets/uploads/2019/ 08/Edited-SPM_Approved_Microsite_FINAL.pdf. Accessed 13 Nov 2019

ISTAT (2016) Poverty in Italy 2015. Italian National Institute of Statistics. http:// www.istat.it/en/archive/poverty. Accessed 11 Aug 2016

Jayaram K (2010) Capital changes: Haitian migrants in contemporary Dominican Republic. Caribb Q 56(3):31-54. https://doi.org/10.1080/00086495.2010.11672372

Kaushal N, Waldfogel J, Wight VR (2014) Food insecurity and SNAP participation in Mexican immigrant families: the impact of the outreach initiative. B E J Economic Anal Policy 14(1):203-240. https://doi.org/10.1515/bejeap-20130083

Kaiser L (2008) Why do low-income women not use food stamps? Findings from the California Women's Health Survey. Public Health Nutr 11 (12):1288-1295. https://doi.org/10.1017/S1368980008002528

Kaiser B, Keys H, Foster J et al. (2015) Social stressors, social support, and mental health among Haitian migrants in the Dominican Republic. Pan-American. J Public Health 38(2):157-162

Kasper J, Gupta SK, Tran P, Cook JT et al. (2000) Hunger in legal immigrants in California, Texas, and Illinois. Am J Public Health 90(10):1629-1633. https:// doi.org/10.2105/AJPH.90.10.1629

Kay C (2006) Rural poverty and development strategies in Latin America. J Agrarian Change 6(4):455-508

Kenny C (2011) Haiti doesn't need your old t-shirt. Foreign Policy. November

Kirkpatrick SI, Tarasuk V (2008) Food insecurity is associated with nutrient inadequacies among Canadian adults and adolescents.J Nutr 138:604-612

Leventhal S (2013) A gap between ideals and reality: the right to health and the inaccessibility of healthcare for Haitian migrant workers in the Dominican Republic. Emory Int Law Rev 27(2):1249-1289

Loopstra R, Reeves A, Stuckler D (2015) Rising food insecurity in Europe. Lancet 385(9982):P2041

Maggini N (2018) The social and political dimensions of solidarity in Italy. In: Lahusen Christian, Grasso MariaT (eds) Solidarity in Europe: citizens' responses in times of crisis. Palgrave Macmillan, Cham, Switzerland, p. $127-168$

Mares TM (2013) "Here We Have the Food Bank": Latino/a Immigration and the contradictions of eemergency food. Food Foodways 21(1):1-21. https://doi. org/10.1080/07409710.2013.764783

Mares TM (2019) Life on the other border: farmworkers and food justice in Vermont. University of California Press, Berkeley, Los Angeles

Martin MS, Maddocks E, Chen Y et al. (2016) Food insecurity and mental illness: disproportionate impacts in the context of perceived stress and social isolation. Public Health 132:86-91. https://doi.org/10.1016/j.puhe.2015.11.014

Maynard M, Dean J, Rodriguez PI et al. (2019) The experience of food insecurity among immigrants: a scoping review. J Int Migr Integr 20(2):375-417. https://doi.org/10.1007/s12134-018-0613-x

McMichael P (2009) A food regime genealogy. J Peasant Stud 36(1):139-169

Mendenhall E (2012) Syndemic suffering: social distress, depression, and diabetes among Mexican immigrant women. Left Coast Press, Walnut Creek

Menjívar C (2012) Legal violence: immigration law and the lives of Central American immigrants. Am J Sociol 117(5):1380-1421

Messer E, Cohen MJ (2007) The human right to food as a US nutrition concern, 1976-2006. (IFPRI Discussion Paper No. 731). Washington, D.C. International food Policy Research Institute

Migration Policy Institute (2011) "Post-9/11 Policies Dramatically Alter the U.S. Immigration Landscape.” http://www.migrationpolicy.org/article/post-911policies-dramatically-alter-us-immigration-landscape. Accessed 21 Oct 2015
Miller T (2013) How the US militarized the haiti-dominican republic border Mother Jones: https://www.motherjones.com/politics/2013/11/border-patrolus-haiti-dominican-republic. Accessed 4 Mar 2020

Mittal A (2009) The 2008 Food Price Crisis: Rethinking Food Security Policies. G24 Discussion Paper Series, No. 56

Minkoff-Zern L (2019) The new American farmer: immigration, race, and the struggle for sustainability. Massachusetts Institute of Technology Press, Cambridge

Moffat T, Mohammed C, Newbold B (2017) Cultural dimensions of food insecurity among immigrants and refugees. Hum Organ 76(1):15-27

Mollett S, Faria C (2013) Messing with gender in feminist political ecology. Geoforum 45:116-125

Muehlebach A (2012) The moral neoliberal: welfare and citizenship in Italy. University of Chicago Press, Chicago

Muldoon KA, Duff PK, Fielden S et al. (2013) Food insufficiency is associated with psychiatric morbidity in a nationally representative study of mental illness among food insecure Canadians. Soc Psychiatry Psychiatr Epidemiol 48 (5):795-803. https://doi.org/10.1007/s00127-012-0597-3

Munger AL, Lloyd TDS, Speirs KE (2015) More than just not enough: experiences of food insecurity for Latino immigrants. J Immigr Minority Health 17 (5):1585-1587

Nally D (2011) The biopolitics of food provisioning. Trans Inst Br Geogr 36:37-53

Nam Y, Jung HJ (2008) Welfare reform and older immigrants: food stamp program participation and food insecurity. Gerontologist 48(1):42-50. https://doi.org/ $10.1093 /$ geront $/ 48.1 .42$

Newfield C (2016) The great mistake: how we wrecked public universities and how we can fix them. John Hopkins University Press

Nugent C (2019) Why Venezuelan Oil Program in Fueling Massive Street Protests in Haiti. TIME. https://time.com/5609054/haiti-protests-petrocaribe. Accessed 18 Mar 2020

Nyantakyi-Frimpong H, Bezner Kerr R (2017) Land grabbing, social differentiation, intensified migration and food security in northern Ghana. J Peasant Stud 44(2):421-444. https://doi.org/10.1080/03066150.2016.1228629

Olson CM (1999) Nutrition and health outcomes associated with food insecurity and hunger. J Nutr 129:521-524

Osservatorio Migrazioni (2018) V Rapporto Migrazioni in Sicilia 2017. Istituto Arrupe. https://istitutoarrupe.gesuiti.it/wp-content/uploads/sites/34/2018/06/ Comunicato-stampa-V-Rapporto-Migrazioni-in-Sicilia-2017-1.pdf. Accessed 22 Jan 2020

Padilla M (2008) Caribbean Pleasure Industry: tourism, sexuality, and AIDS in the Dominican Republic. University of Chicago Press, Chicago

Passel JS, Cohn D (2011) U.S. unauthorized immigration flows are down sharply since mid-decade. Pew Research Center, Washington, D.C.

Patel R (2007) Stuffed and starved: The hidden battle for the World food system. Random House, New York

Patel R, Holt-Giménez E, Shattuck A (2009) Food rebellions: crisis and the hunger for justice. Food First, Oakland

Pechlaner G, Otero G (2010) The neoliberal food regime: neoregulation and the new division of labor in North America. Rural Sociol 75(2):179-208

Perry K (2009) The groundings with my sisters: toward a black diasporic feminist agenda in the Americas. Scholar Feminist Online 7(2):1-8

Perry K (2014) State violence and the ethnographic encounter: feminist research and racial embodiment. In: Reiter B, Oslender U (eds) Bridging scholarships and activism: reflections from the frontlines of collaborative research. Michigan State University Press, East Lansing, p 151-170

Pfeiffer J, Chapman R (2010) Anthropological perspectives on structural adjustment and public health. Annu Rev Anthropol 39:149-65

Programme des Nations Unies pour le développement (PNUD) (2013) Programme des Nations Unies pour le développement République d'Haïti. 2014. Rapport OMD Haïti: un nouveau regard, Port-au-Prince

Poppendieck J (1998) Sweet charity?: emergency food and the end of entitlement. Penguin, New York

Pottier J (1999) The anthropology of food: the social dynamics of food security. Pottier, Cambridge

Quandt SA, Shoaf JI, Tapia J et al. (2006) Experiences of Latino immigrant families in North Carolina help explain elevated levels of food insecurity and hunger. J Nutr 136(10):2638-2644

Rabben L (2016) Sanctuary and asylum: a social and political history. University of Washington Press, Seattle

Reardon J, TallBear K (2012) Your DNA is our history: genomics, anthropology, and the construction of whiteness as property. Curr Anthropol 53(S12): S233-S245

Reese A (2019) Black food geographies: race, self-reliance, and food access in Washington, D.C. The University of North Carolina Press, Chapel Hill

Sagás E (2000) Race and politics in the Dominican Republic. University Press of Florida, Gainesville 
Salas LM, Ayon C, Gurrola M (2013) Estamos traumados: the effect of antiimmigrant sentiment and policies on the mental health of Mexican immigrant families. J Community Psychol 41(8):1005-1020

Schuller M (2012) Killing with kindness: Haiti, international aid, and NGOs. Rutgers University Press, New Brunswick, New Jersey

Segura DA, Zavella P (2007) Introduction. In women and migration in the USMexico borderlands. Duke University Press, Durham, p 1-32

Shore C, Wright S (1999) Audit culture and anthropology: neo-liberalism in British higher education. J R Anthropological Inst 5(4):557-557

Simmons D (2010) Structural violence as social practice: Haitian agricultural workers, anti-Haitianism, and health in the Dominican Republic. Hum Organ 69(1):10-18

Simmons ES, Smith NR (2019) The case for comparative ethnography. Comp Politics 51(3):341-359

Slopen N, Fitzmaurice G, Williams DR et al. (2010) Poverty, food insecurity, and the behavior for childhood internalizing and externalizing disorders. J Am Acad Child Adolesc Psychiatry 49(5):444-452

Tavernier L (2008) The stigma of blackness: anti-Haitianism in the Dominican Republic. Social Democracy 22(3):96-104

Ticktin M (2011) Casualties of care: immigration and the politics of humanitarianism in France. University of California Press, Berkeley, Los Angeles

UNHCR (2020) What is a refugee? The UN Refugee Agency. http://unrefugees.org

US Census (2011) Income, poverty and health insurance coverage in the United States, 2010. USC Bureau

US Census Bureau (2010) American community survey. http://www.census.gov/acs

Van Hook J, Balistreri KS (2006) Ineligible parents, eligible children: food stamps receipt, allotments, and food insecurity among children of immigrants. Soc Sci Res 35(1):228-251. https://doi.org/10.1016/j.ssresearch.2004.09.001

Van Hook, J, Bean, F, Passel J (2005) Unauthorized migrants living in the United States: a mid-decade portrait, Migration Policy Institute

Vahabi M, Damba C (2013) Perceived barriers in accessing food among recent Latin American immigrants in Toronto. Int J Equity Health 12(1):11. https:// doi.org/10.1186/1475-9276-12-1

Vahabi M, Damba C, Rocha C et al. (2011) Food insecurity among Latin American recent immigrants in Toronto. J Immigr Minority Health 13(5):929-939. https://doi.org/10.1007/s10903-010-9384-y

Viruell-Fuentes EA, Miranda PY, Abdulrahim S (2012) More than culture: structural racism, intersectionality theory, and immigrant health. Soc Sci Med 75 (12):2099-2106

Vita (2019) Crescono gli irregolari in Italia, saranno 670 mila il prossimo anno. http://www.vita.it/it/article/2019/10/24/crescono-gli-irregolari-in-italiasaranno-670mila-il-prossimo-anno/153091/. Accessed 21 Nov 2019

Vozoris NT, Tarasuk NS (2003) Household food insufficiency is associated with poorer health. J Nutr 133(1):120-126

Walsemann KM, Ro A, Gee GC (2017) Trends in food insecurity among California residents from 2001 to 2011: Inequities at the intersection of immigration status and ethnicity. Preventive Med 105:142-148. https://doi.org/10.1016/j. ypmed.2017.09.007

Weaver LJ, Hadley C (2009) Moving beyond hunger and nutrition: a systematic review of the evidence linking food insecurity and mental health in developing countries. Ecol Food Nutr 48(4):263-284

Weeks J (ed) (1995) Structural adjustment and the agricultural sector in Latin America and the Caribbean. Macmillan, London

World Bank (2019a) World Bank national accounts data, and OECD National Accounts data files: Haiti https://data.worldbank.org/indicator/NY.GDP. MKTP.CD?locations=HT. Accessed 11 Oct 2019

World Bank (2019b) World Bank national accounts data, and OECD National Accounts data files: Dominican Republic. https://data.worldbank.org/ country/dominican-republic. Accessed 11 Oct 2019
World Bank (2019c) Personal remittances, received (\% of GDP): Haiti. https://data worldbank.org/indicator/BX.TRF.PWKR.DT.GD.ZS?locations=HT. Accessed 21 Nov 2019

World Bank (2017) International Tourism Number of Arrivals Data: https://data. worldbank.org/indicator/ST.INT.ARVL?locations=DO\&view=map. Accessed 4 Mar 2020

Yates-Doerr E (2015) The weight of obesity: hunger and global health in postwar Guatemala. University of California Press, Berkeley, Los Angeles

Young S (2008) Season of hunger: a crisis of food inflation and shrinking safety nets in the United States. The Oakland Institute, Oakland

Zavella P (2011) I'm neither here nor there: Mexican's Quotidian struggles with migration and poverty. Duke University Press, Durham

Zanotti L (2010) Cacophanies of aid: failed statebuilding and NGOs in Haiti. Third World Q 31(5):755-711

Zincone G (2006) Italian immigrants and immigration policy-making: Structures, actors and practices. IMISCOE Working Paper

\section{Acknowledgements}

We would like to thank those that provided funding support for our respective research projects, including UC-MEXUS, the Chicano Studies Institute (UC Santa Barbara), Institute for Research on Labor and Employment (UCLA), Center for Global Studies (University of Washington), Center for Western European Studies (University of Washington), Research, Development, and Innovation (University of Arizona), the Tinker Foundation, and the Michael Mikhael Family Global Health Fund. Finally, we would also like to thank the UA College of Social and Behavioral Sciences and the Center for Regional Food Studies for supporting the publication of this article.

\section{Competing interests}

The authors declare no competing interests.

\section{Additional information}

Correspondence and requests for materials should be addressed to M.A.C.

Reprints and permission information is available at http://www.nature.com/reprints

Publisher's note Springer Nature remains neutral with regard to jurisdictional claims in published maps and institutional affiliations.

Open Access This article is licensed under a Creative Commons Attribution 4.0 International License, which permits use, sharing,
adaptation, distribution and reproduction in any medium or format, as long as you give appropriate credit to the original author(s) and the source, provide a link to the Creative Commons license, and indicate if changes were made. The images or other third party material in this article are included in the article's Creative Commons license, unless indicated otherwise in a credit line to the material. If material is not included in the article's Creative Commons license and your intended use is not permitted by statutory regulation or exceeds the permitted use, you will need to obtain permission directly from the copyright holder. To view a copy of this license, visit http://creativecommons.org/ licenses/by/4.0/.

(C) The Author(s) 2020 